\title{
Courtyard Housing and Cultural Sustainability in China
}

\section{Donia Zhang, PhD}

Director, Neoland School of Chinese Culture, Canada Associate, City Institute, York University

University of Toronto, Munk School of Global Affairs and Public Policy Asian Institute and Contemporary Asian Studies Student Union January 16, 2015 


\section{Structure of the Presentation}

๑. Four pillars of sustainable development

(.) Four key themes in Chinese philosophy

๑. Traditional courtyard houses and their decline

(1) New courtyard housing development in China

(.) Four cornerstones of culturally sustainable architecture

(.) Proposals for new courtyard-garden houses 


\section{Four Pillars of Sustainable Development}

๑. Environmental responsibility

๑) Economic viability

Social equity

๑ Cultural vitality

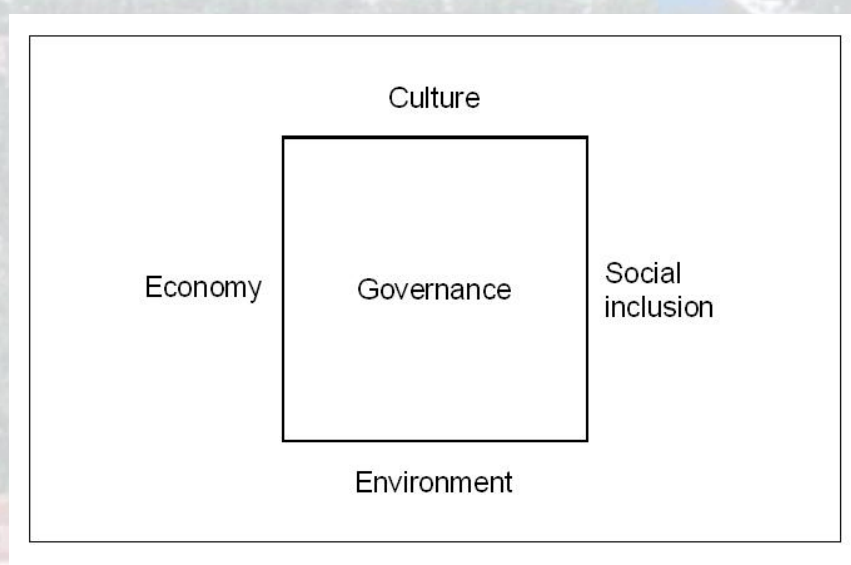

The accepted 4-pillar sustainable development framework. Source: after UNESCO, 2006 


\section{Four Key Themes in Chinese Philosophy}

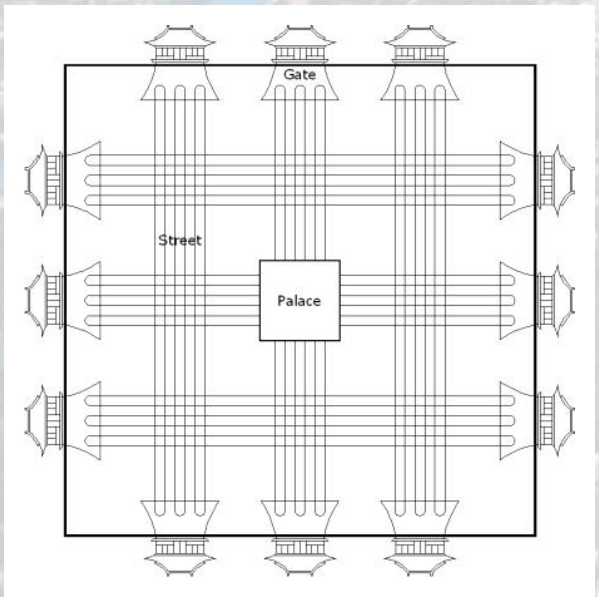

The ideal capital city in imperial China from the Record of Trades in Rituals of Zhou (c.1066-221 BCE). All the measurements within it are multiples of heavenly number 3. Drawing by Donia Zhang after Liu, 2002

\begin{tabular}{|c|c|c|}
\hline $\begin{array}{c}\text { 私 } \\
\text { Private }\end{array}$ & $\begin{array}{c}\text { 私 } \\
\text { Private }\end{array}$ & $\begin{array}{c}\text { 私 } \\
\text { Private }\end{array}$ \\
\hline $\begin{array}{c}\text { 私 } \\
\text { Private }\end{array}$ & $\begin{array}{c}\text { 公 } \\
\text { Public }\end{array}$ & $\begin{array}{c}\text { 私 } \\
\text { Private }\end{array}$ \\
\hline $\begin{array}{c}\text { 私 } \\
\text { Private }\end{array}$ & $\begin{array}{c}\text { 私 } \\
\text { Private }\end{array}$ & $\begin{array}{c}\text { 私 } \\
\text { Private }\end{array}$ \\
\hline
\end{tabular}

The Nine Squares System (井田制). Drawing by Donia Zhang based on the Complete Chinese Dictionary, 1915; Chinese-English Dictionary, 1980

(.) Harmony with Heaven - form and environmental quality

(. Harmony with Earth - space and construction quality

๑ Harmony with Humans - matters of social cohesion

๑. Harmony with Self - time and cultural activities 


\section{Courtyard Houses across China}

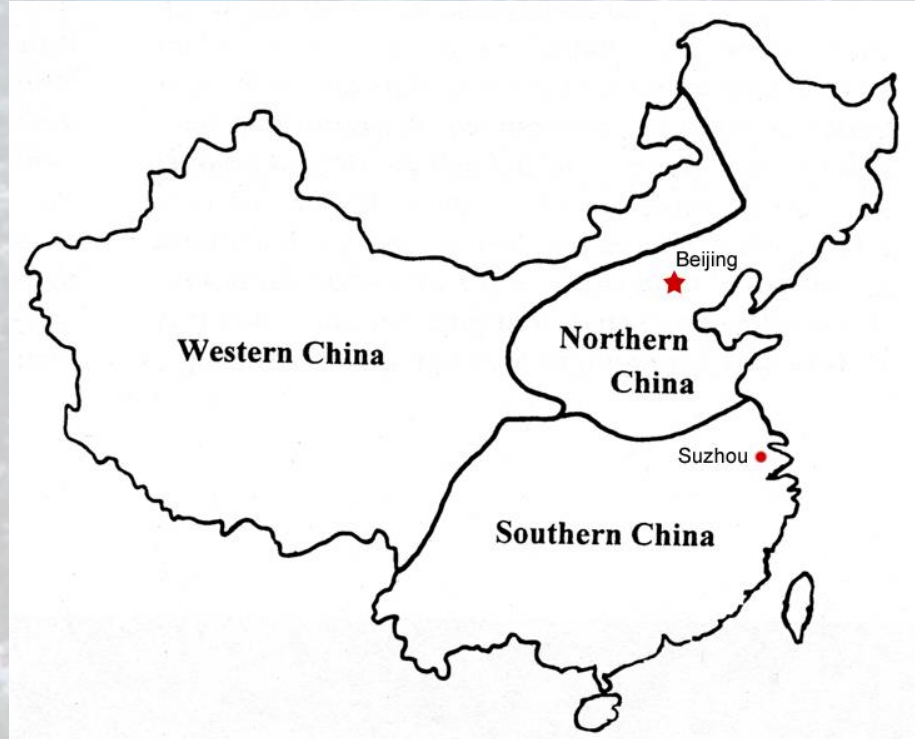

Map of China showing the northern, southern, and western divisions with locations of Beijing and Suzhou as my case study cities. Source: Knapp, 2000, p. 2

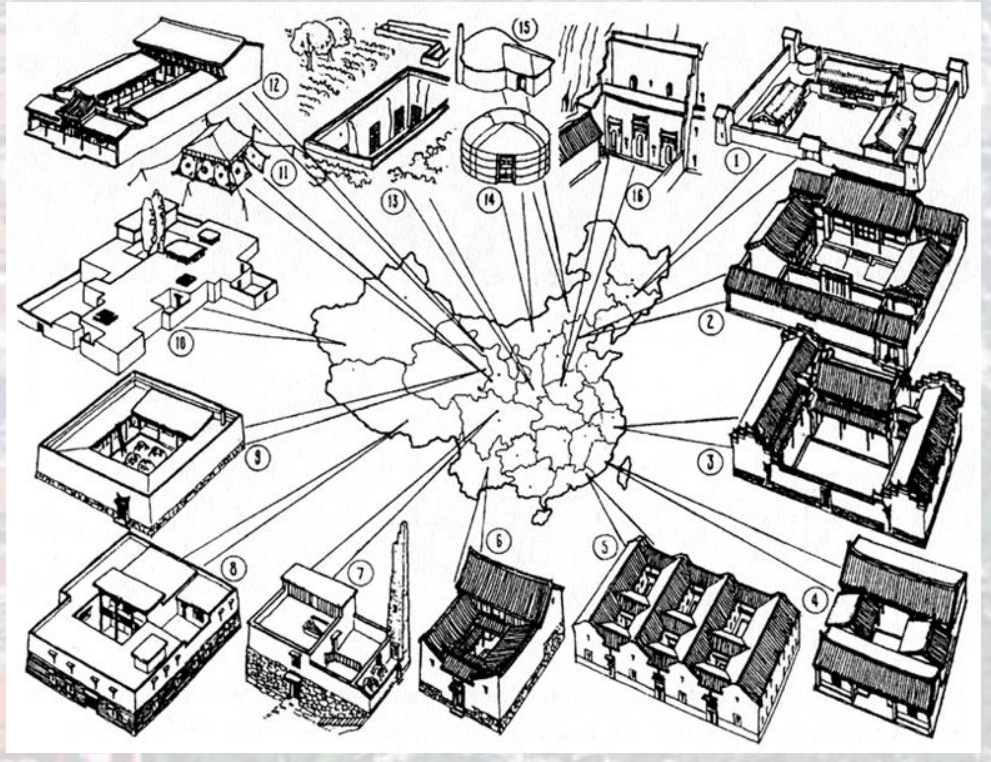

House types across China showing the courtyard as a common feature. Source: Drawing by Fu Xinian in Liu, 1990, p. 206

(.) The Chinese have lived in single-extended-family courtyard houses in many parts of China for thousands of years

- The courtyard can offer many advantages

๑. Traditional Chinese courtyard houses were grouped as northern, southern, and western types 


\section{City of Beijing}

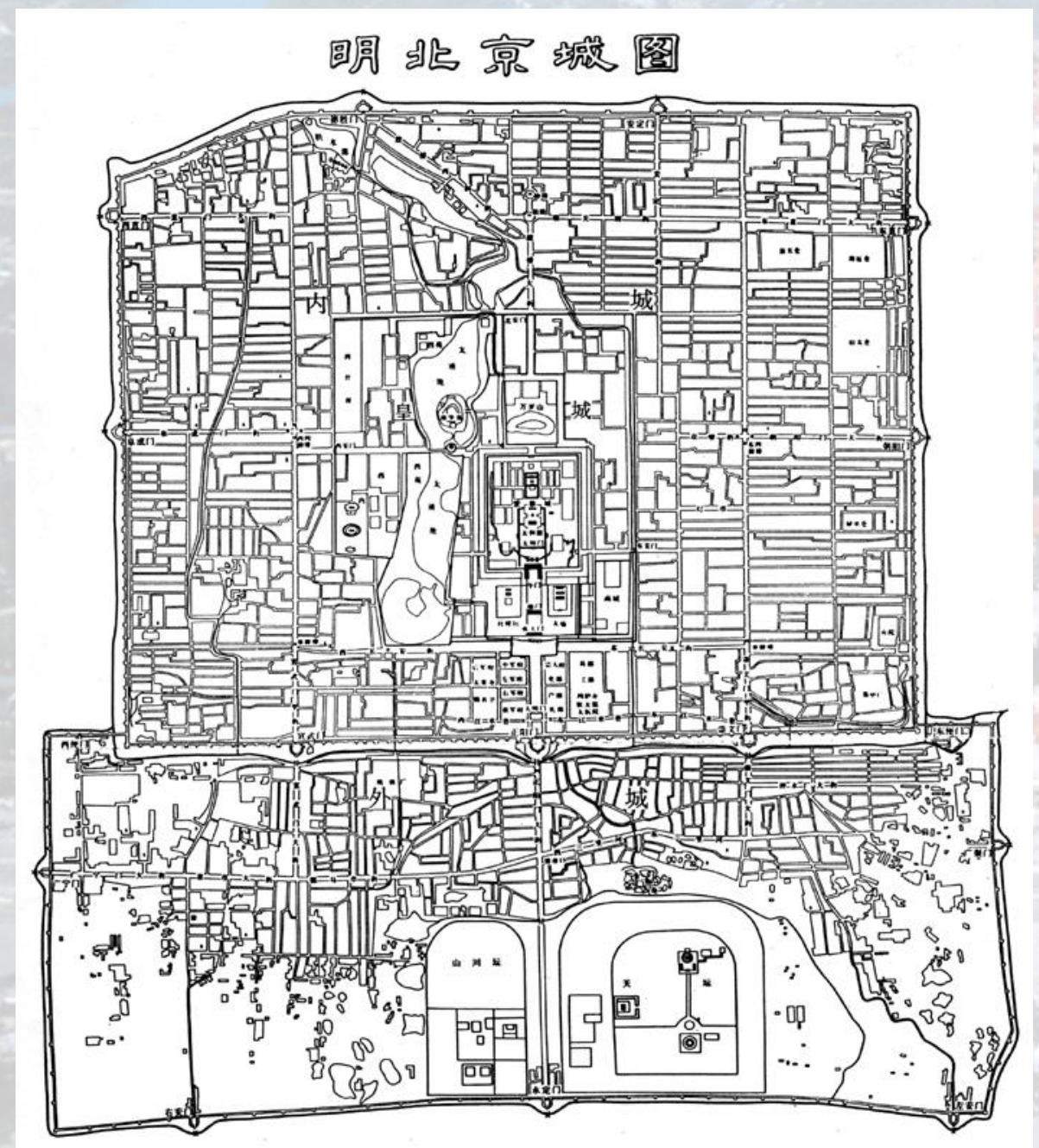

Beijing during the Ming dynasty (1368-1644). Source: Dong, 1987

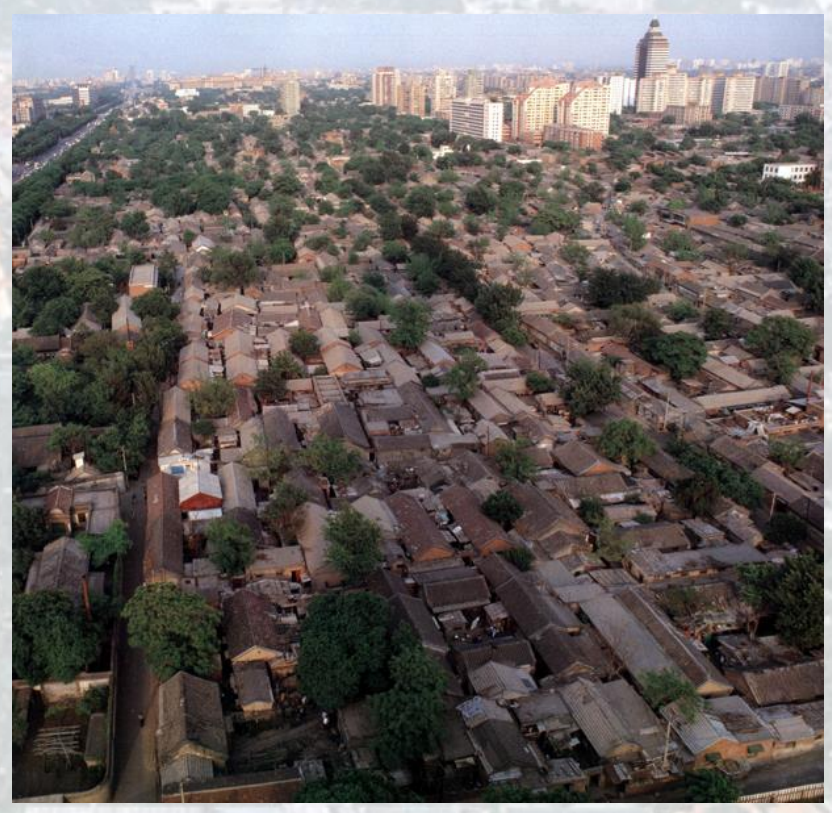

Traditional courtyard houses and hutong (lanes) in an old residential district of Beijing. Source: Ma, 1993, p. 2

Beijing is a northern Chinese city with a rich history of over 3,000 years and as China's capital for over 800 years; its famous siheyuan (courtyard houses) with strict axial, symmetrical, and hierarchical planning embody the Confucian ideal of "harmony in social relationships." 


\section{Courtyard Houses of Beijing}

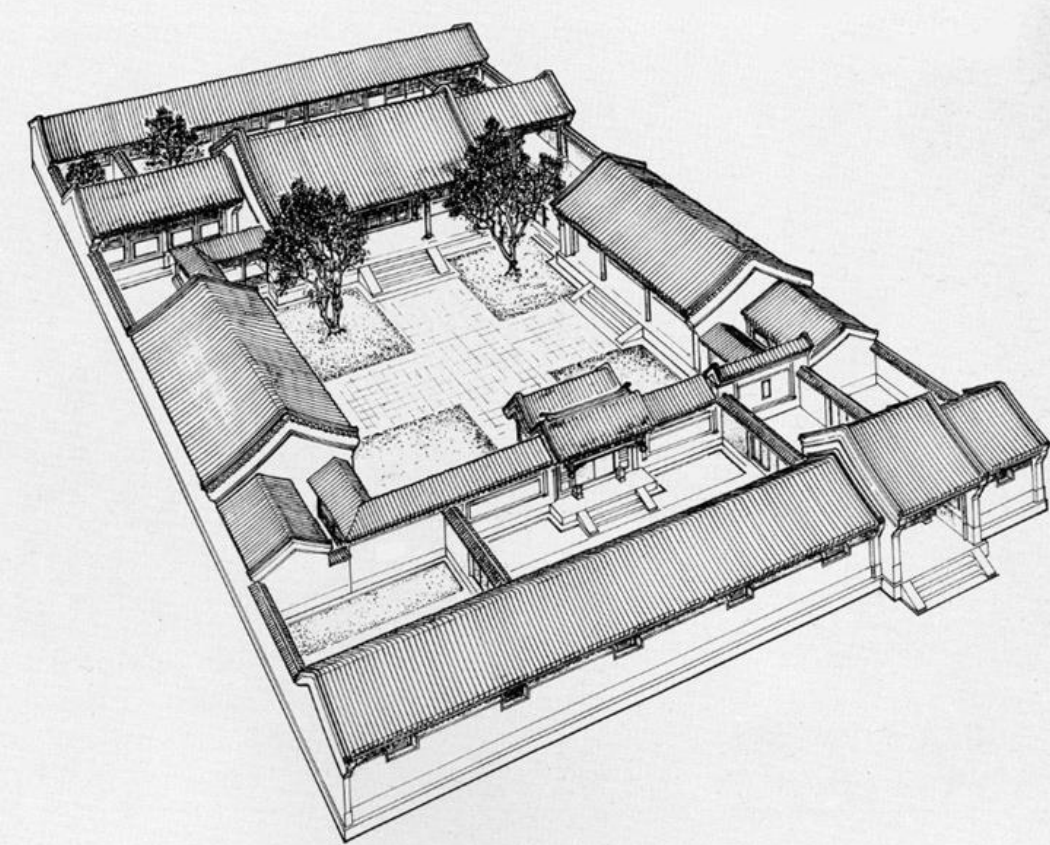

A typical or standard three-courtyard house of Beijing. Source: Ma, 1999, p. 7

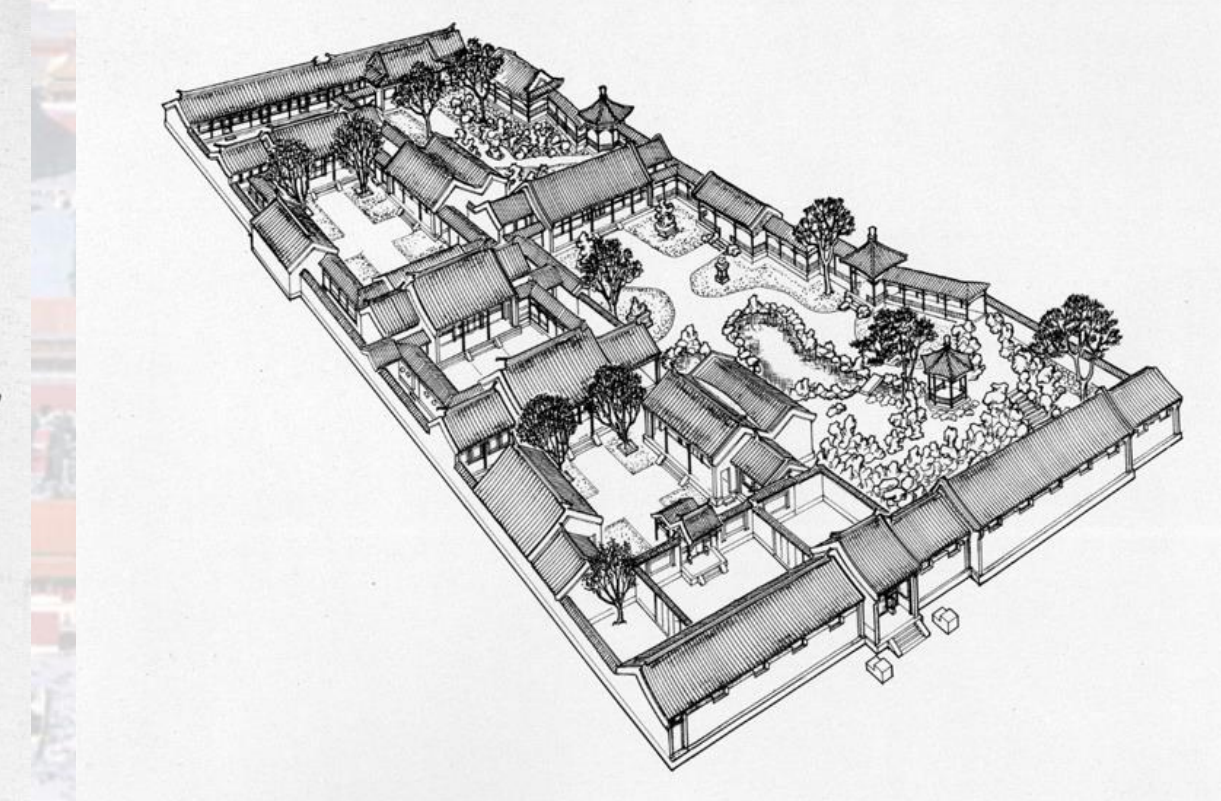

A large, five-courtyard house with gardens in Beijing. Source: Ma, 1999, p. 227 


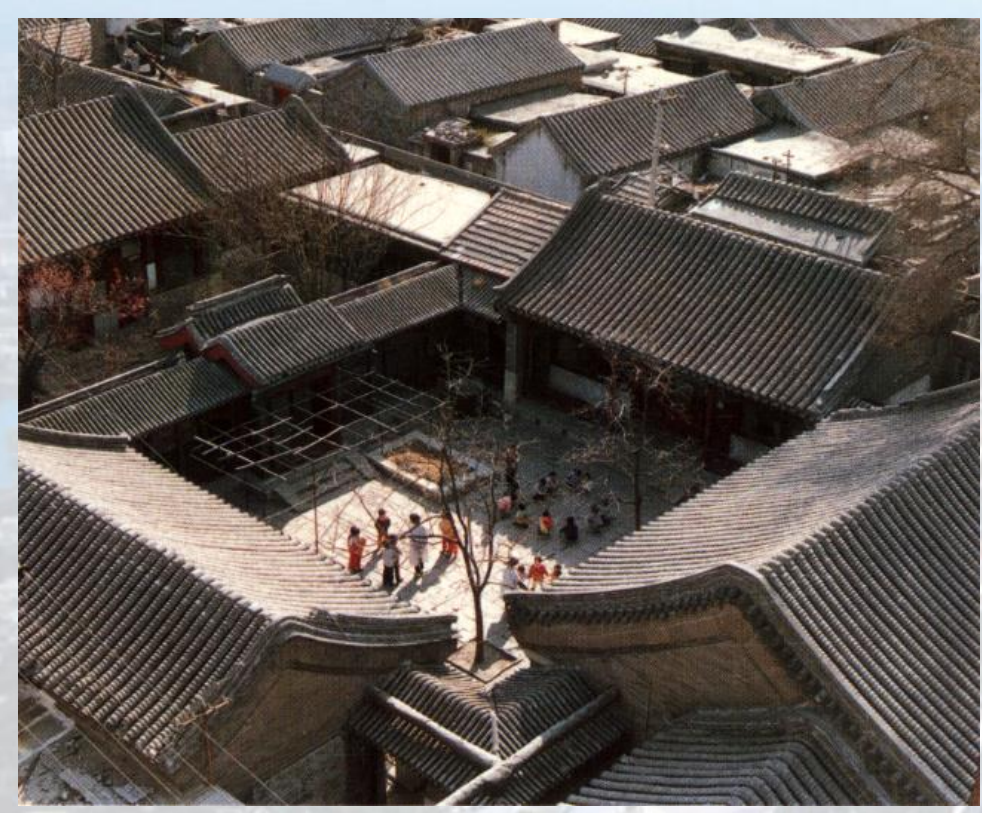

Children playing in a traditional courtyard of Beijing. Source: Ma, 1993, p. i

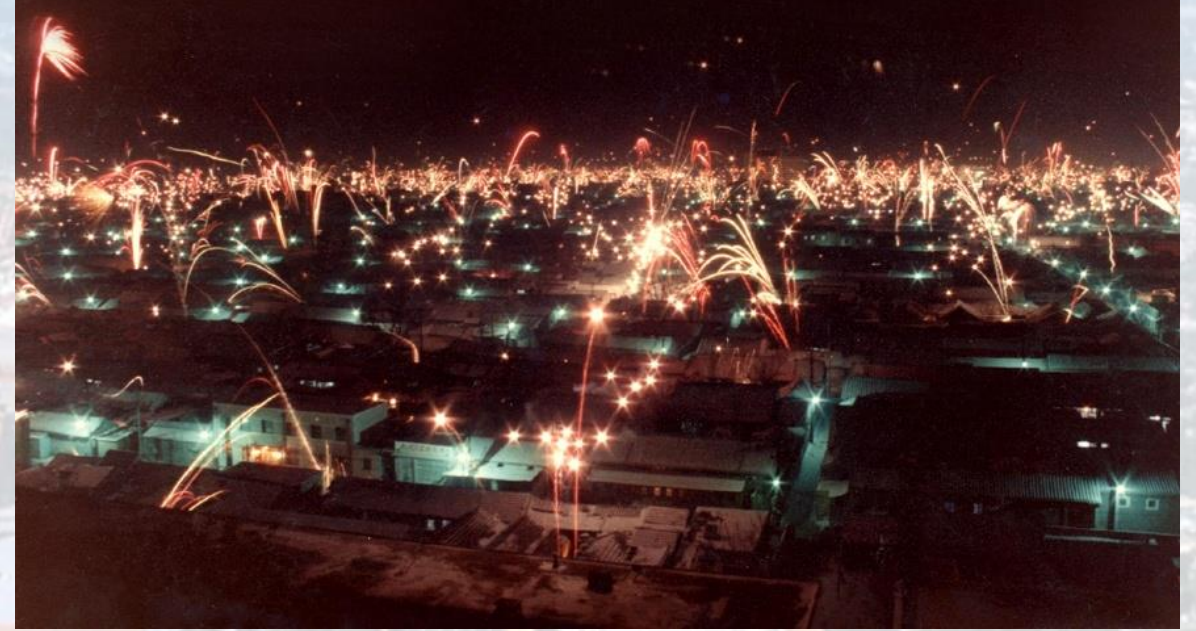

Fireworks lit in Beijing courtyards on Chinese New Year's Eve. Photo: Junmin Zhang 1988

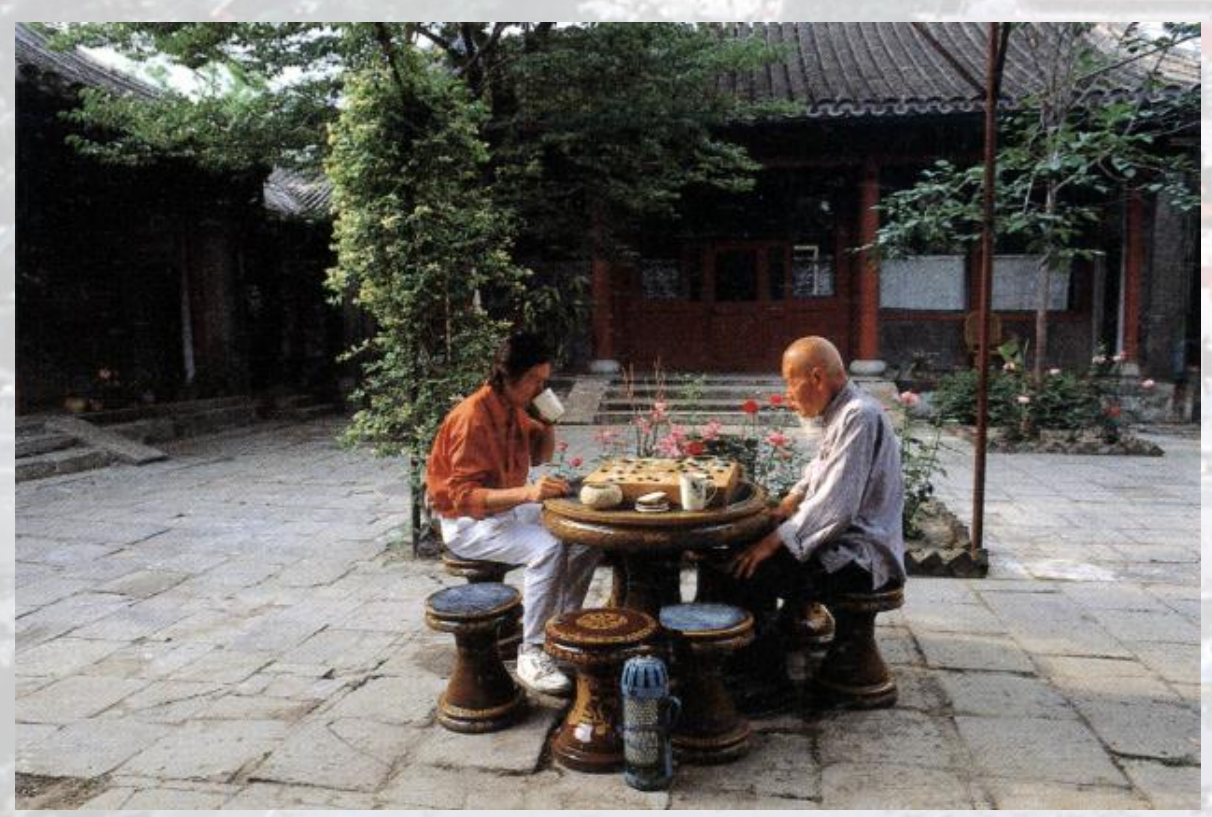

Playing games in a traditional courtyard of Beijing. Source: Ma, 1993, p. 39

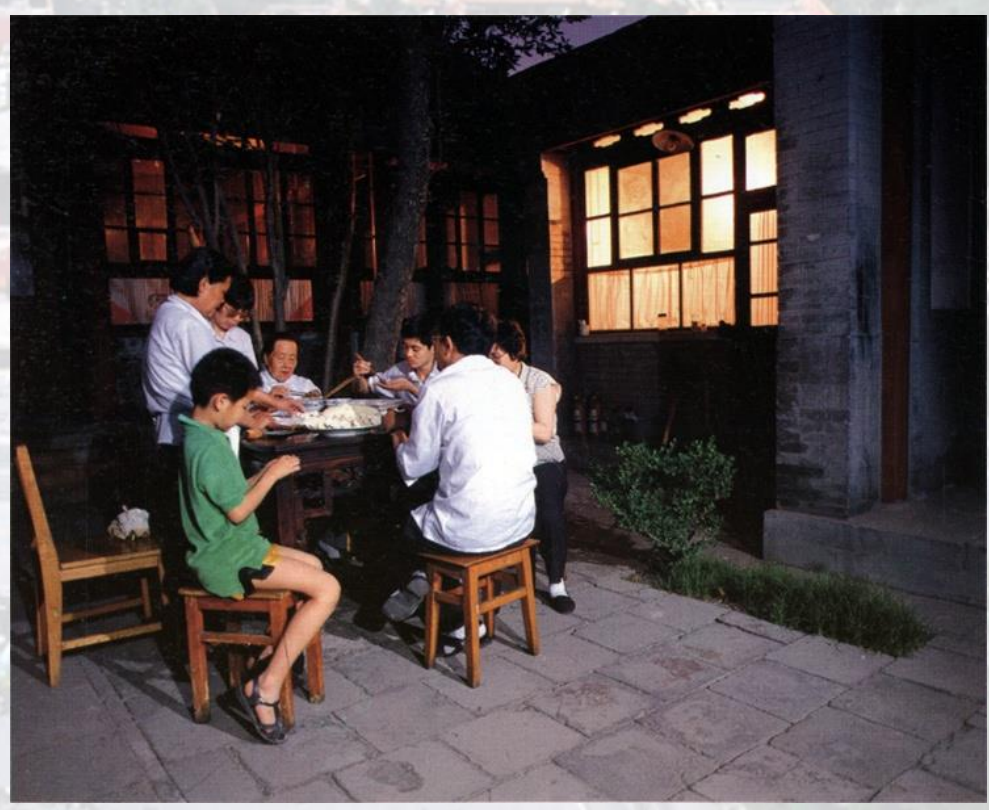

Making dumplings in a traditional courtyard of Beijing. Source: Ma, 1993, p. 44 


\section{City of Suzhou}
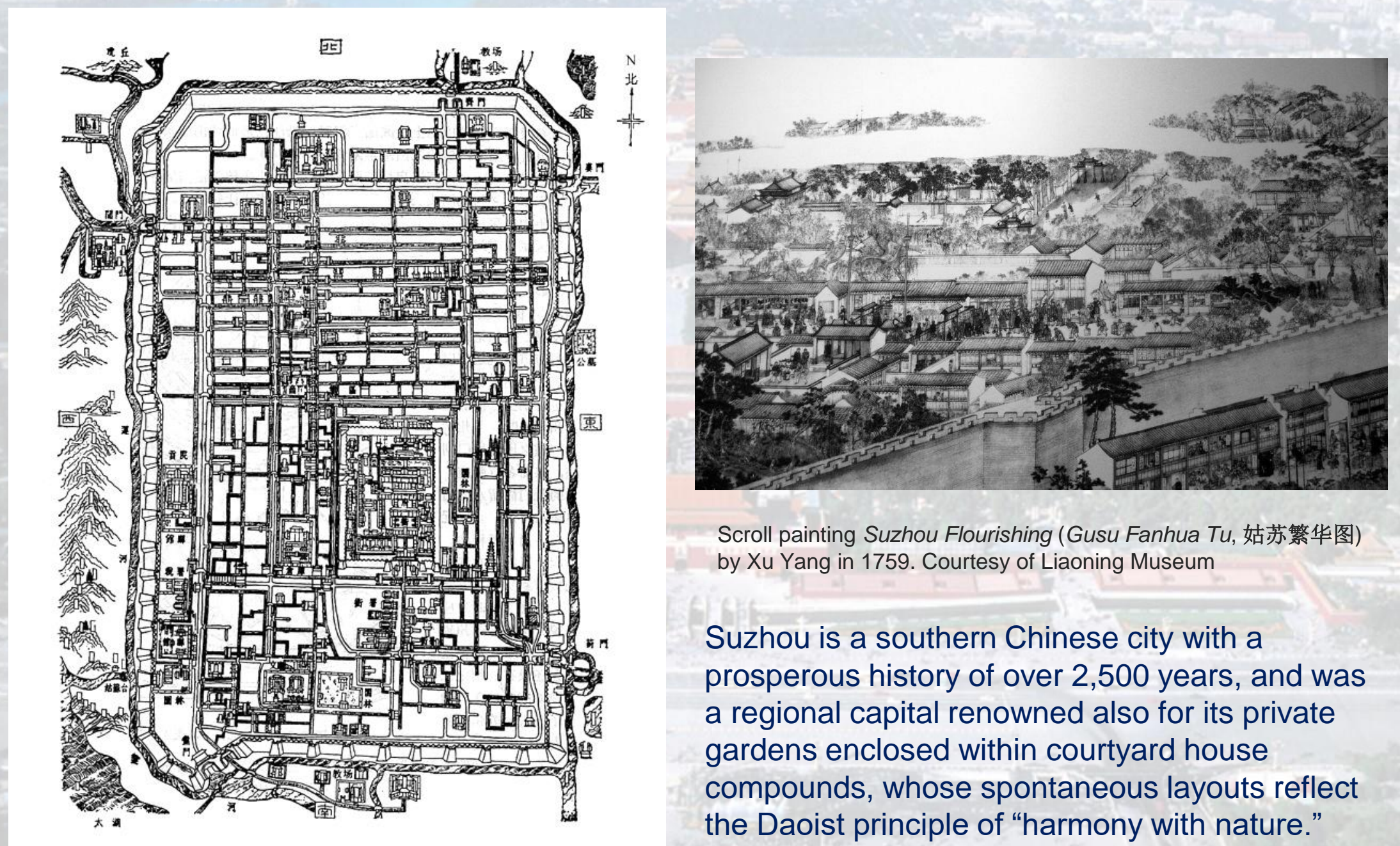

Scroll painting Suzhou Flourishing (Gusu Fanhua Tu, 姑苏繁华图) by Xu Yang in 1759. Courtesy of Liaoning Museum

Suzhou is a southern Chinese city with a prosperous history of over 2,500 years, and was a regional capital renowned also for its private gardens enclosed within courtyard house compounds, whose spontaneous layouts reflect the Daoist principle of "harmony with nature."

Pingjiang/Suzhou map from a stone stela in 1229.

Source: History of Chinese Architecture, 1986, p. 56 


\section{Courtyard Houses in Southern China}

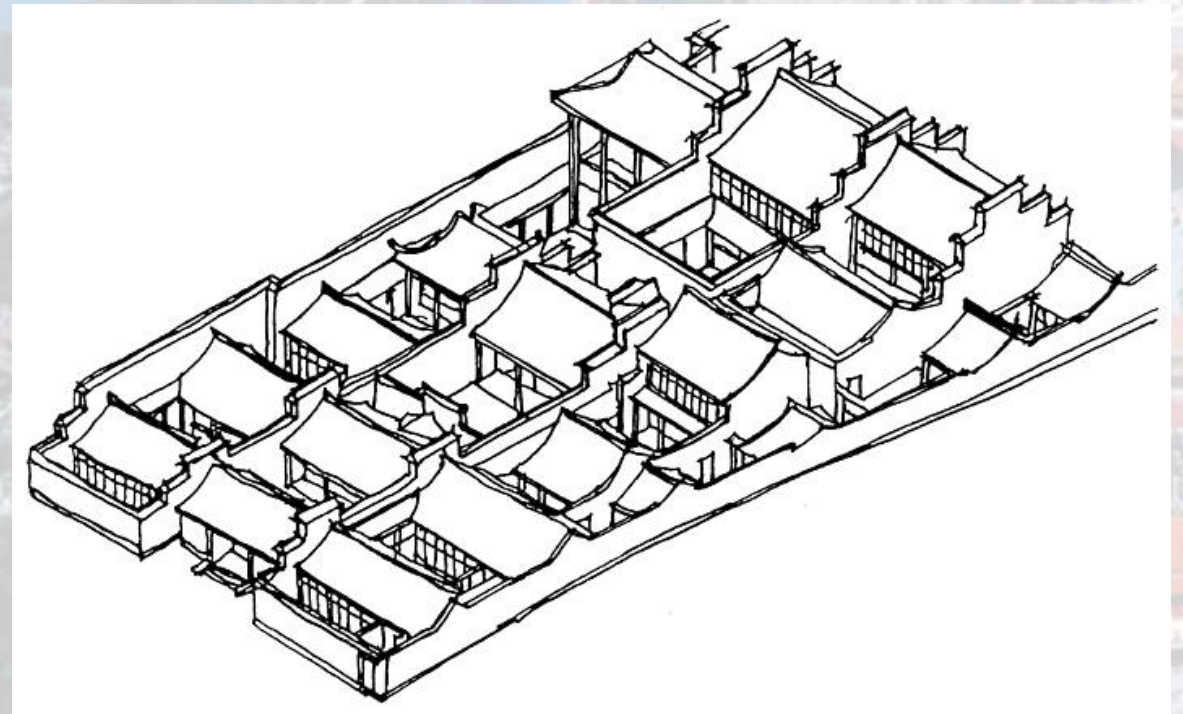

A large classical courtyard house in Suzhou.

Source: Wu, 1991, p. 58

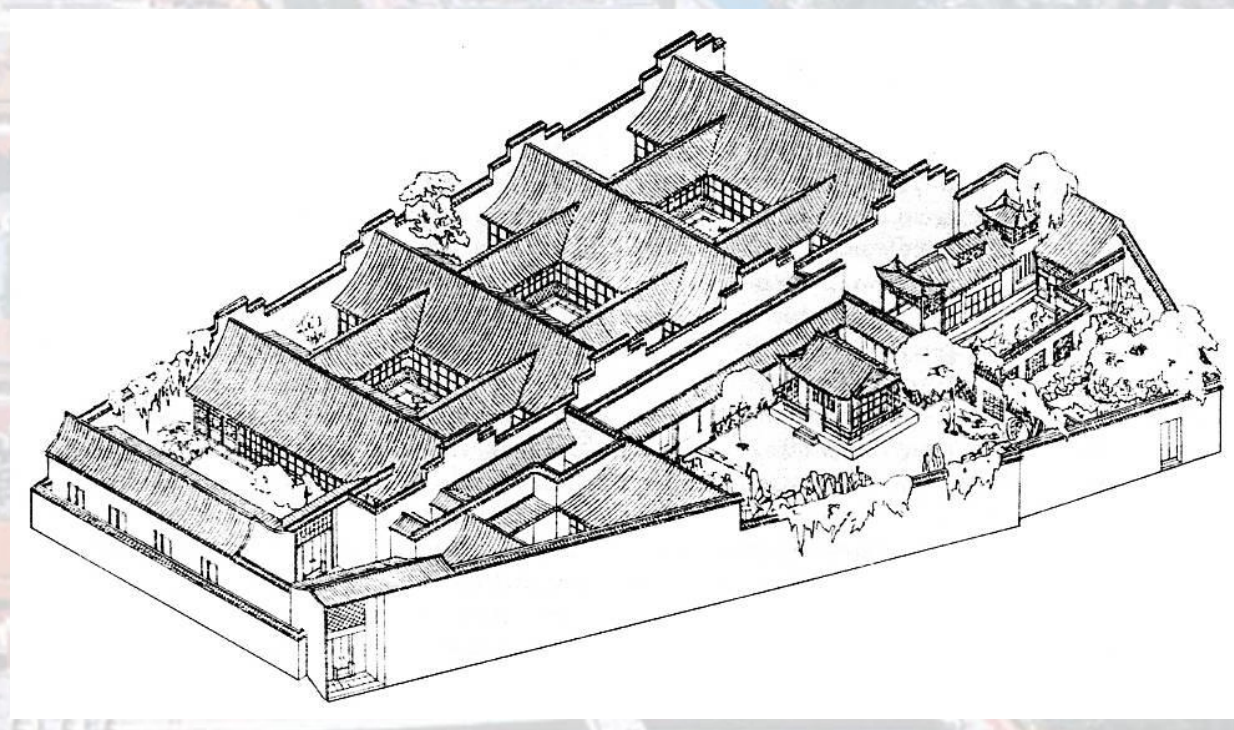

A large classical courtyard house in Yangzhou. Source: Schinz, 1989, p. 58 

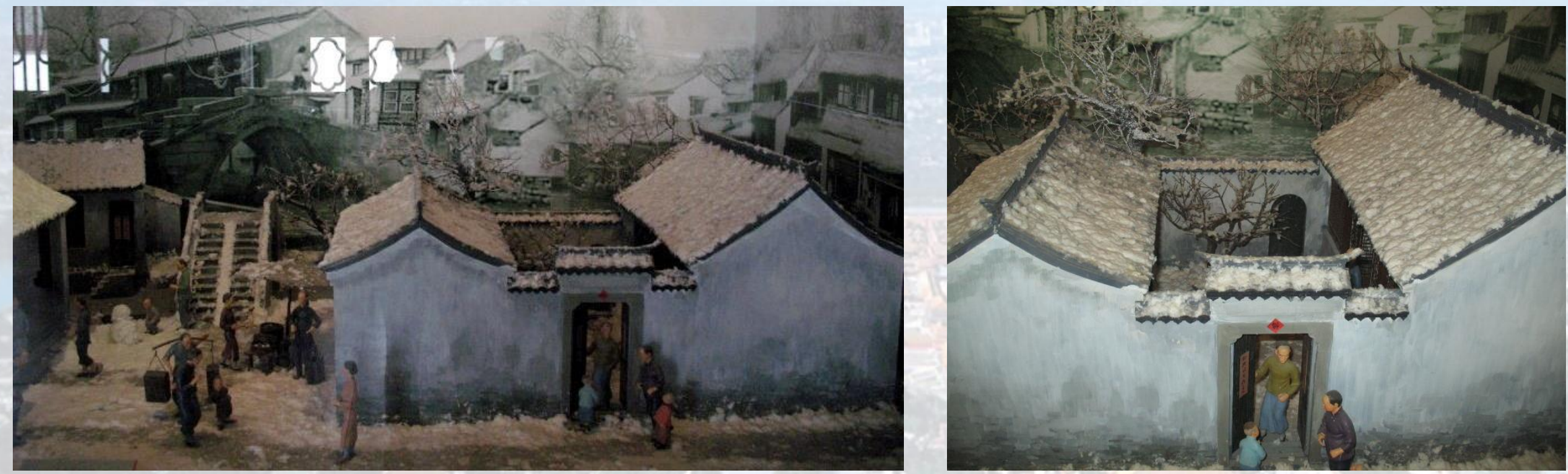

Model of a small riverside courtyard house in Suzhou Folk Custom Exhibition Centre. Photos by Donia Zhang 2007
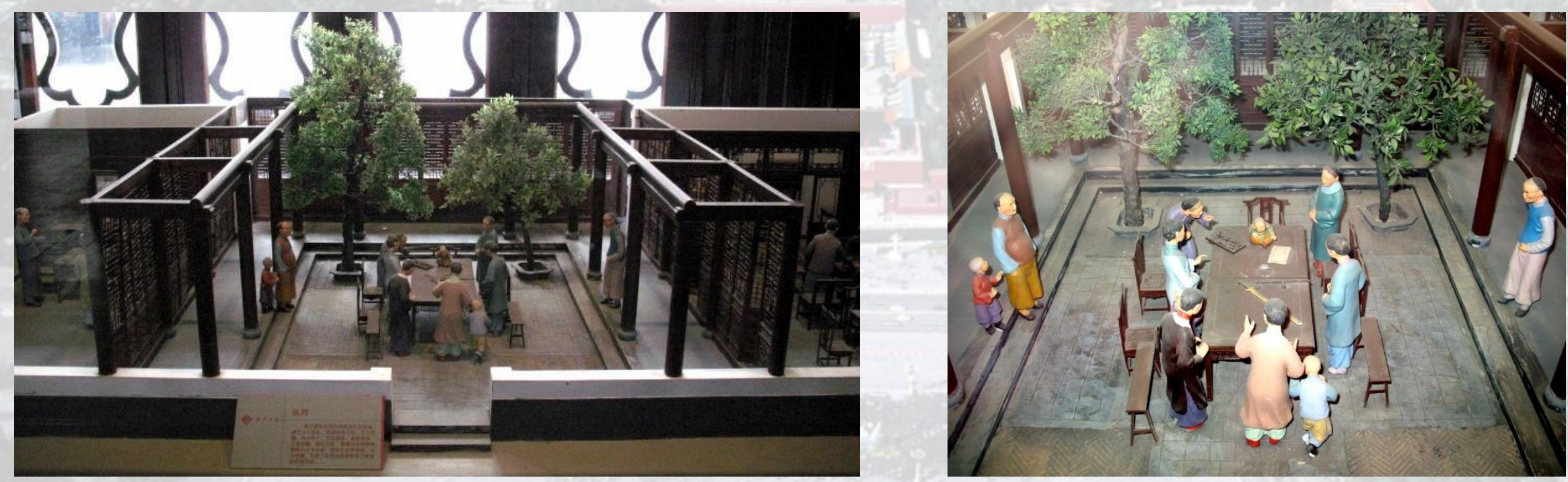

Model of a classical courtyard house in Suzhou Folk Custom Exhibition Centre depicting zhuazhou in the courtyard. Photos by Donia Zhang 2007 


\section{Decline of Traditional Courtyard Houses}

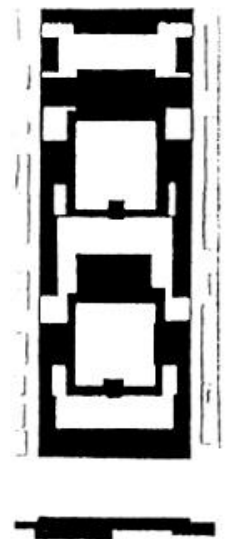

$1950 \mathrm{~s}$

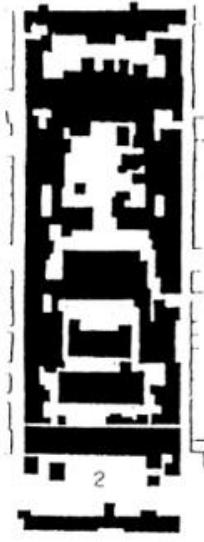

1970 s

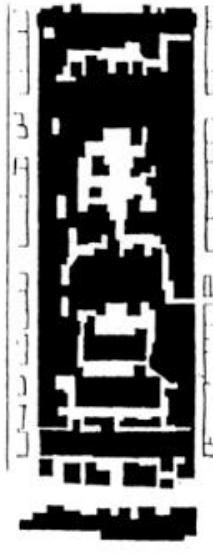

1980 s
The decline of a courtyard house compound in Beijing from early 1950s-1970s-1980s. Source: Zhu and Fu, 1988

(. China's population more than doubled between 1953 and 2010

(. However, the average household size in China has decreased from singleextended to nuclear families

๑. The change in Chinese family structure demands a subsequent change in housing form 


\section{Demolition of Traditional Courtyard Houses}

Table 1. Destruction and conservation of siheyuan and hutong in inner Beijing

\begin{tabular}{|c|l|c|}
\hline Year & \multicolumn{1}{|c|}{\begin{tabular}{c} 
Siheyuan (courtyard house) \\
\hline 1949
\end{tabular}} & \begin{tabular}{c} 
Hutong (lane) \\
\hline 100 percent (of 62 sqkm of inner-city land area)
\end{tabular} \\
\hline 1990 & $\begin{array}{l}1.9 \text { percent (805 courtyard houses in relatively good condition } \\
\text { in the conservation areas) }\end{array}$ & 3900 \\
\hline 2003 & $\begin{array}{l}1.5 \text { percent (658 courtyard houses in relatively good condition } \\
\text { in the conservation areas) }\end{array}$ & 1570 \\
\hline 2004 & $\begin{array}{l}1.3 \text { percent (539 courtyard houses in relatively good condition } \\
\text { in the conservation areas) }\end{array}$ & 1200 \\
\hline
\end{tabular}

Sources: Abramson, 2001; Beijing City Planning Chart, 2007; Collins, 2005; Kong, 2004; Ornelas, 2006 


\section{Renewal of Traditional Courtyard Houses}

๑. Since 2005, Beijing Municipal Government has been restoring traditional courtyard houses

(1) However, the renewal did not solve problems of small living space, and many communal courtyards have become even smaller and caused disputes among neighbors

๑. Thus, decreased spaces in communal courtyards have had a negative impact on social relations among neighbors 


\section{Redevelopment of New Courtyard Housing}

\section{Table 2. New courtyard housing estates constructed in China since the $1990 \mathrm{~s}$}

\begin{tabular}{|c|c|c|c|c|c|c|}
\hline City & Name of Estates & Year of Completion & Number of Units & Number of Floors & Size of Units & Size of Courtyards \\
\hline \multirow{2}{*}{ Beijing } & $\begin{array}{l}\text { Juer Hutong } \\
\text { (菊儿胡同 } \\
\text { "Chrysanthemum } \\
\text { Lane") }\end{array}$ & 1990-1994 & 210 & $\begin{array}{l}\text { 2-3-storey walk-up } \\
\text { apartments }\end{array}$ & $40-120 \mathrm{sqm}$ & $\begin{array}{l}13 \mathrm{~m} \times 15 \mathrm{~m} ; \\
6.5 \mathrm{~m} \times 7.5 \mathrm{~m}\end{array}$ \\
\hline & $\begin{array}{l}\text { Nanchizi (南池子 } \\
\text { "South Pond") }\end{array}$ & 2003 & 301 & $\begin{array}{l}\text { 2-storey row/town } \\
\text { houses }\end{array}$ & $45-75$ sqm & $\begin{array}{c}\text { 7-9 m (distance } \\
\text { between buildings) }\end{array}$ \\
\hline \multirow{3}{*}{ Suzhou } & $\begin{array}{l}\text { Tongfangyuan } \\
\text { (桐芳苑 “Aleurites } \\
\text { Cordata Fragrant } \\
\text { Garden Housing } \\
\text { Estate”) }\end{array}$ & 1996 & 220 & $\begin{array}{l}\text { 2-storey row/town } \\
\text { houses, 2-storey } \\
\text { courtyard garden } \\
\text { villas, and 3-storey } \\
\text { walk-up apartments }\end{array}$ & $70-200 \mathrm{sqm}$ & $\begin{array}{l}\text { 10-12 m (distance } \\
\text { between buildings) }\end{array}$ \\
\hline & $\begin{array}{l}\text { Jiaanbieyuan } \\
\text { (佳安别院 } \\
\text { “Excellent Peace } \\
\text { Garden Housing } \\
\text { Estate”) }\end{array}$ & 1998 & 600 & $\begin{array}{l}\text { 2-storey row/town } \\
\text { houses, and 4-6- } \\
\text { storey walk-up } \\
\text { apartments }\end{array}$ & $90-180 \mathrm{sqm}$ & $\begin{array}{c}\text { Ratio of building } \\
\text { height to distance is } \\
1: 1.3\end{array}$ \\
\hline & $\begin{array}{l}\text { Shilinyuan (狮林苑 } \\
\text { “Lion Grove Garden } \\
\text { Housing Estate") }\end{array}$ & 2000 & 232 & $\begin{array}{l}\text { 3-storey row/town } \\
\text { houses, and 3-4- } \\
\text { storey walk-up } \\
\text { apartments }\end{array}$ & $90-180 \mathrm{sqm}$ & $\begin{array}{l}8-13.5 \mathrm{~m} \text { (distance } \\
\text { between buildings) }\end{array}$ \\
\hline
\end{tabular}



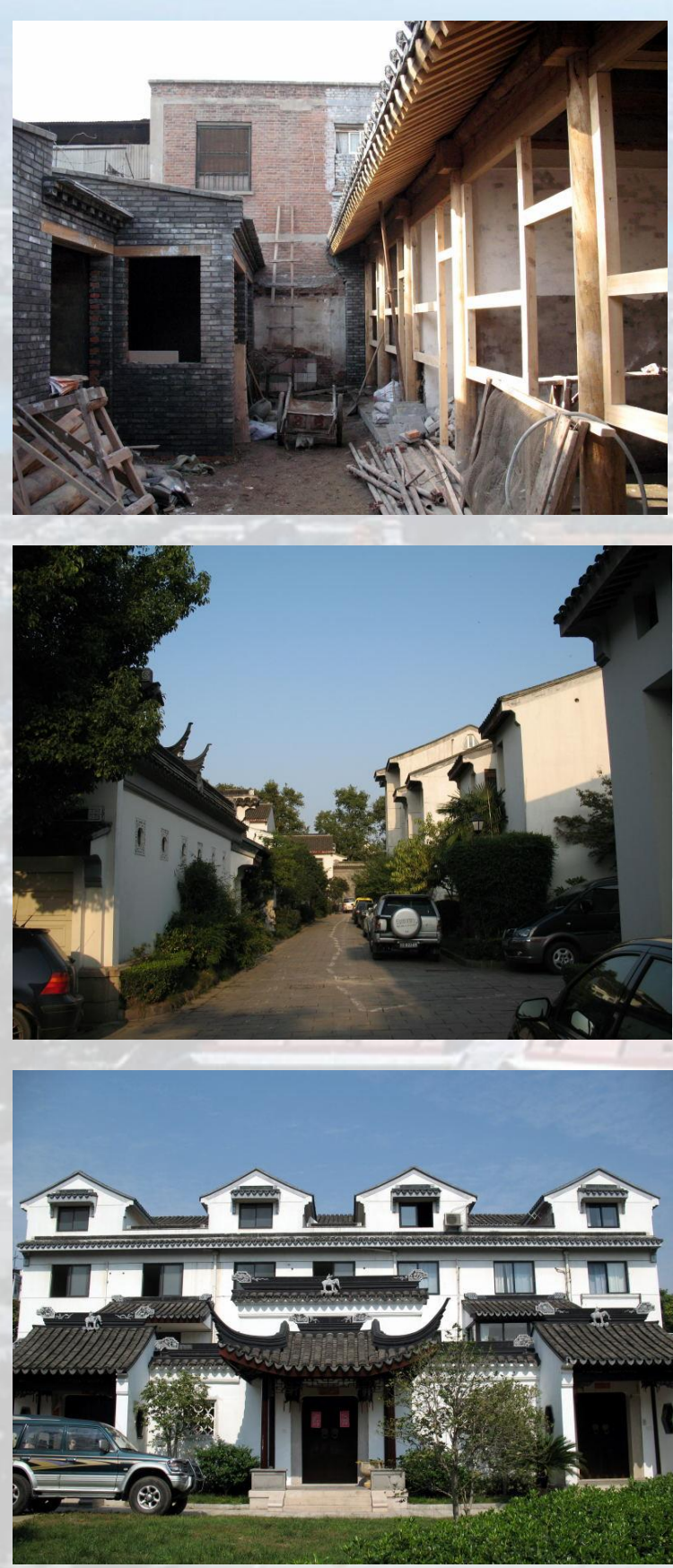

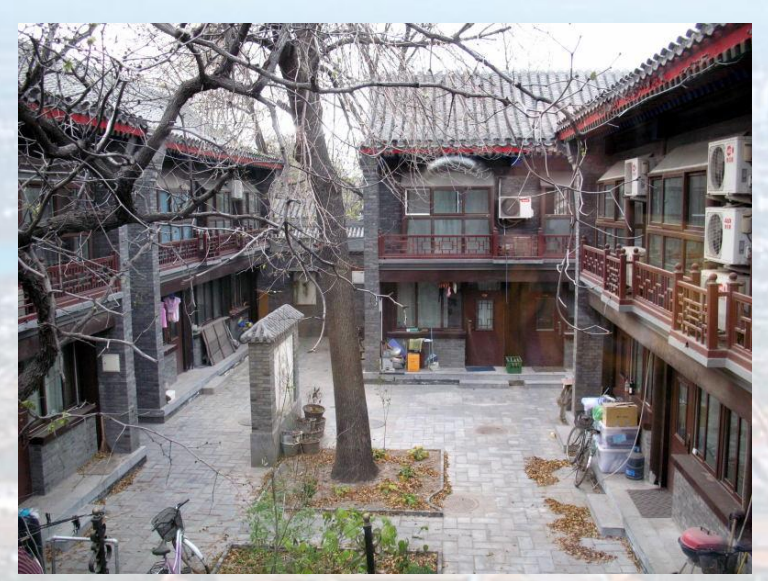

New Courtyard Housing built in Beijing and Suzhou since the 1990s All Photos by Donia Zhang 2007
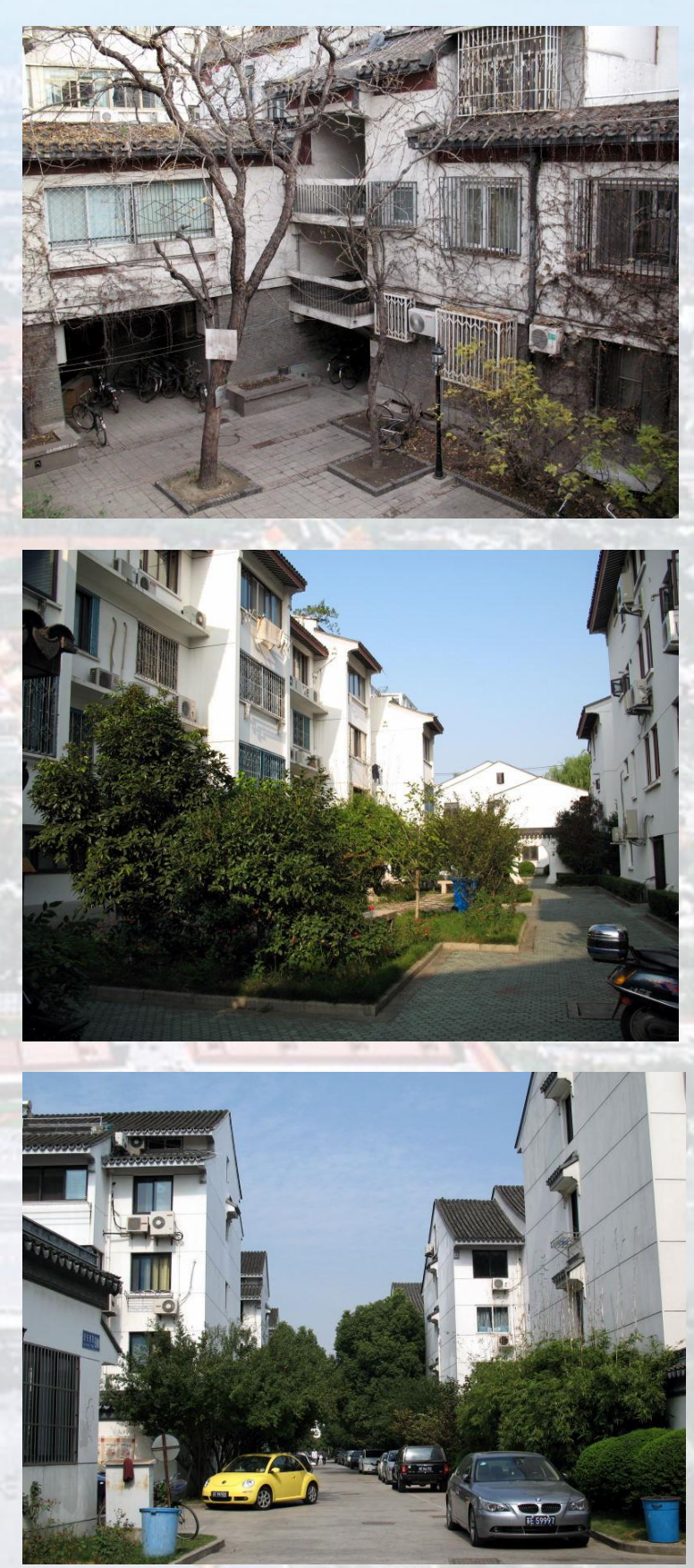

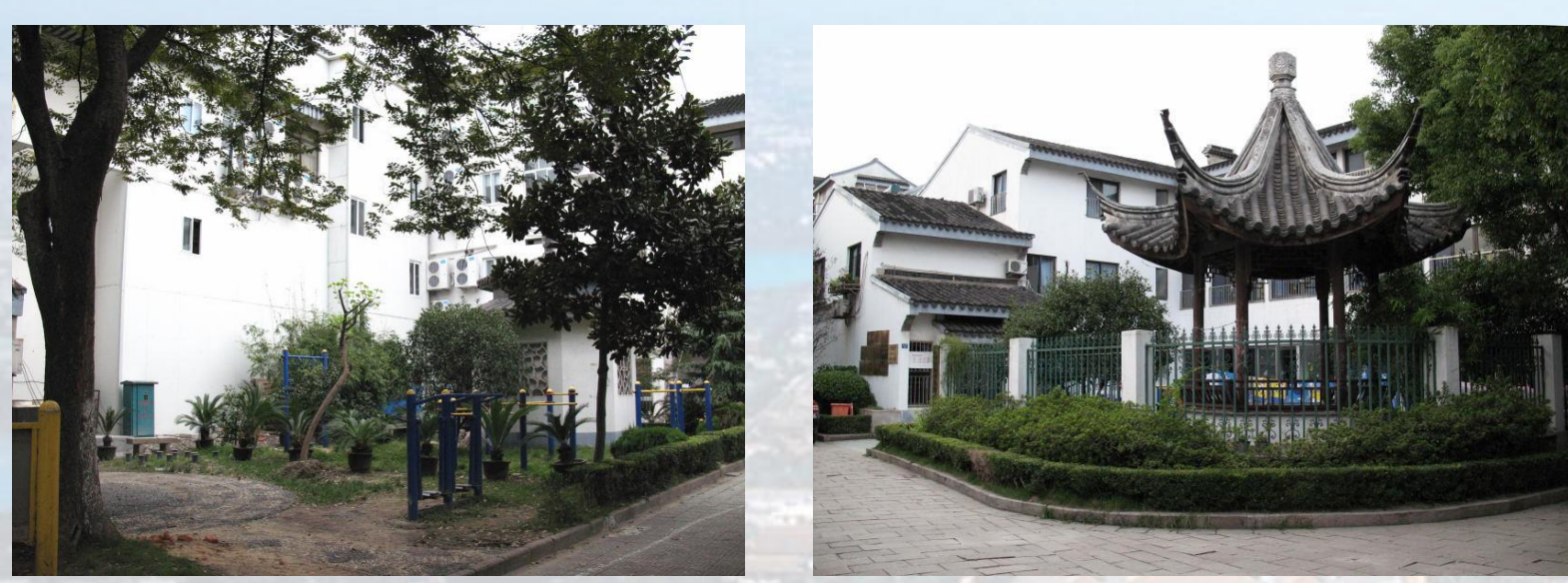

New Communal

Central Gardens in the Suzhou Cases

All Photos by Donia Zhang 2007
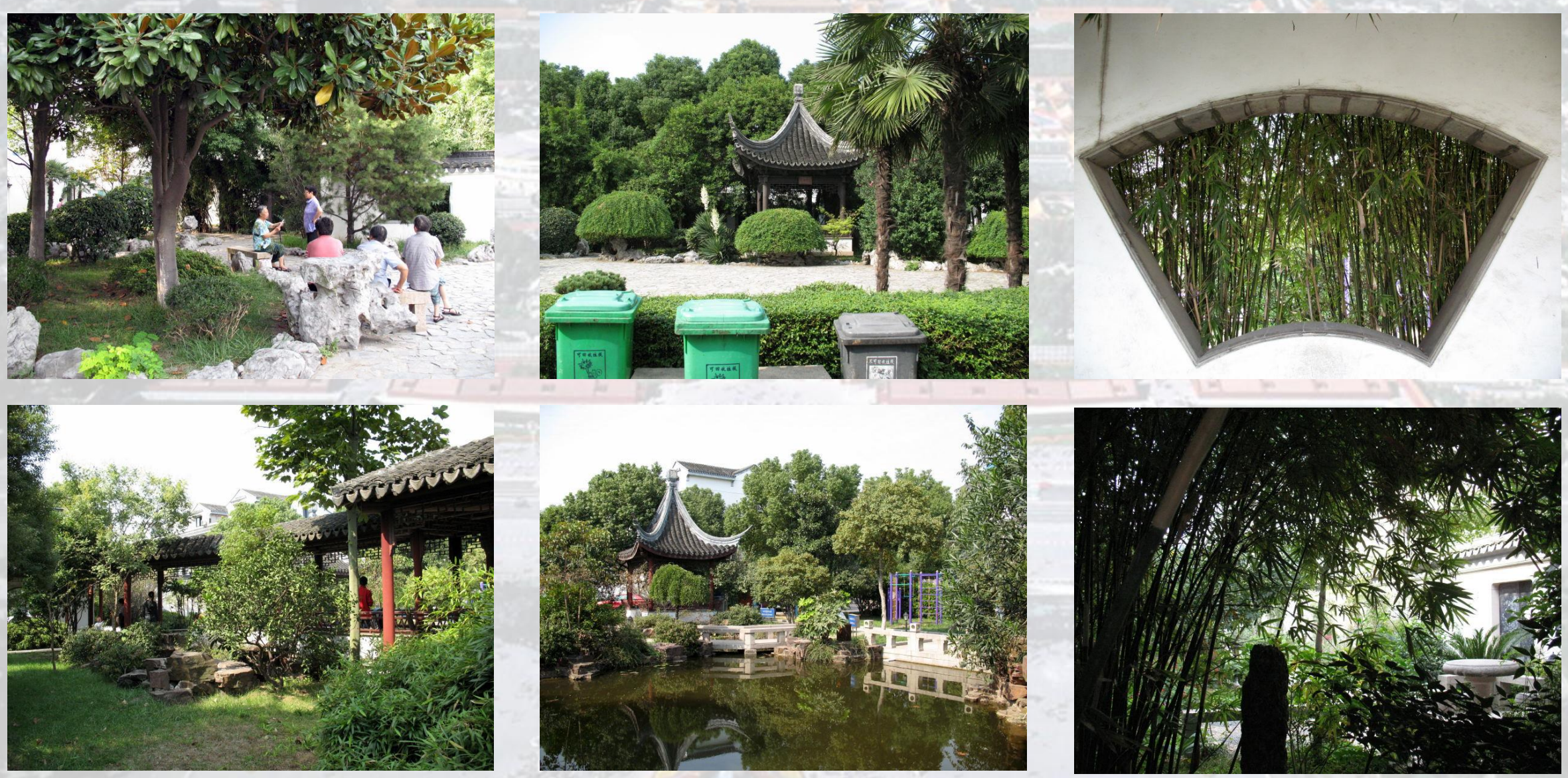


\section{Form and Space of the New Courtyard Housing}

(. The results reveal that the new courtyards are generally too small to admit enough sunlight

(.) The ratio of building height to distance should be at least 1:3 for Beijing (Zhang, 2006, 2011) and 1:1.3 for Suzhou

๑. The interior spaces of new courtyard housing are generally small in Beijing Nanchizi and Juer Hutong, they are larger and more satisfactory in Suzhou Shilinyuan and Jiaanbieyuan

(2) Interior space of $120-180$ sqm per unit for a 3-4-person household is generally satisfactory

(. Most residents prefer to live in low-rise housing of 1-3 storeys for practical reasons, and living close to the earth (Feng Shui) is still preferred

(.) Residents have expressed a preference for pitched roofs than flat ones because they have experienced better thermal performance of pitched roofs 


\section{Social Cohesion and Cultural Activities in the New Courtyard Housing}

(.) The findings also suggest that communal courtyards foster social interaction and private courtyards facilitate self-cultivation

(.) Neighborly relations are partly influenced by the form and space of the courtyard housing

(. Neighborly relations are partly influenced by a changing and polarizing society, socio-economic differences, housing tenure, modern lifestyles, community involvement, common language, cultural awareness, and the cultural background of the residents

(.) The communal courtyards help sustain some traditional Chinese cultural activities. The primary function of a communal courtyard is to maintain health/natural healing

(.) Many cultural activities are much less or no longer partaken in the communal courtyards, likely due to such factors as time, climate, courtyard ownership, yard size, facilities, and so on 


\section{Four Cornerstones of \\ Culturally Sustainable Architecture}

\section{Table 3. Four cornerstones of culturally sustainable architecture in China}

\begin{tabular}{|c|c|c|c|}
\hline \multicolumn{2}{|c|}{$\begin{array}{l}\text { Material/dwelling culture } \\
\text { (archi-culture, tangible) }\end{array}$} & \multicolumn{2}{|c|}{$\begin{array}{l}\text { Immaterial/spiritual culture } \\
\text { (socio-culture, intangible) }\end{array}$} \\
\hline $\begin{array}{l}\text { Harmony with Heaven: form } \\
\text { and environmental quality }\end{array}$ & $\begin{array}{l}\text { Harmony with Earth: space } \\
\text { and construction quality }\end{array}$ & $\begin{array}{l}\text { Harmony with Humans: } \\
\text { matters of social cohesion }\end{array}$ & $\begin{array}{l}\text { Harmony with Self: time and } \\
\text { cultural activities }\end{array}$ \\
\hline $\begin{array}{ll}\text { - } & \text { Exterior form } \\
\text { - } & \text { Exterior walls } \\
\text { - } & \text { Gate and access } \\
\text { - } & \text { Windows } \\
\text { - } & \text { Courtyards and gardens } \\
\text { - } & \text { Roofs }\end{array}$ & $\begin{array}{ll}\text { - } & \text { Interior space } \\
\text { - } & \text { Floor levels } \\
\text { - } & \text { materials } \\
\text { - } \quad \text { Facility provision } \\
\text { Building materials and } \\
\text { construction quality } \\
\text { Maintenance and } \\
\text { management } \\
\text { - Car park spaces }\end{array}$ & $\begin{array}{l}\text { Education, occupation, } \\
\text { and house-purchasing } \\
\text { power } \\
\text { Social relations among } \\
\text { neighbors } \\
\text { Relations with foreign } \\
\text { neighbors } \\
\text { Indoor-outdoor visual } \\
\text { interactions }\end{array}$ & $\begin{array}{l}\text { Philosophy and religion } \\
\text { - } \quad \text { Cultural activities at } \\
\text { home } \\
\text { Cultural activities in } \\
\text { courtyards } \\
\text { Cultural activities in } \\
\text { community/city } \\
\text { parks/gardens } \\
\text { Cultural festivities } \\
\text { indoors and outdoors } \\
\text { Birthday celebrations } \\
\text { Wedding ceremony or } \\
\text { anniversary celebrations }\end{array}$ \\
\hline
\end{tabular}




\section{Proposed Beijing New Courtyard-Garden Houses}
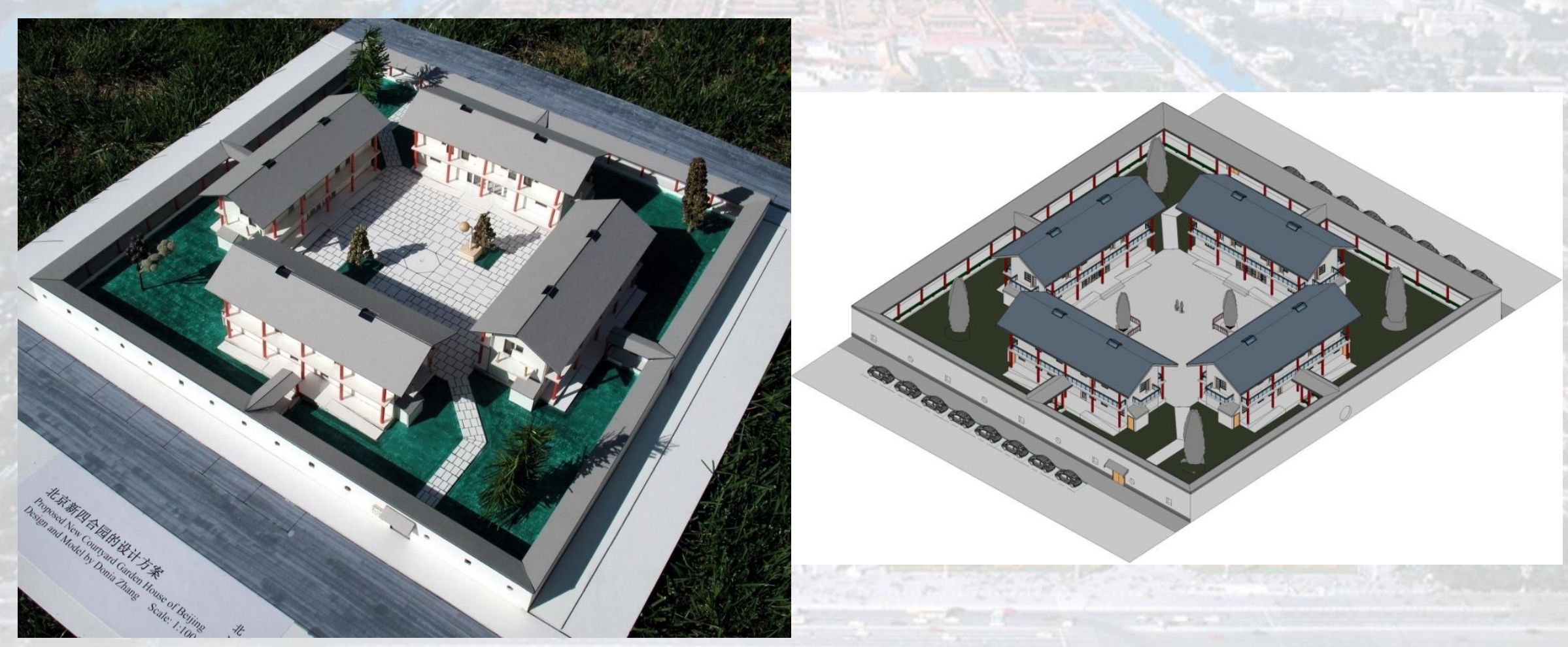

Models of the proposed Beijing new courtyard-garden house compound based on a system of $60 \mathrm{~m} \times 60 \mathrm{~m}$ standard block size, the common courtyard is $26 \mathrm{~m} \times 26 \mathrm{~m}$ shared by 8 nuclear families, and each household also enjoys a private garden at the back. Each housing unit measures $6 \mathrm{~m} \times 10 \mathrm{~m}$ (total $180 \mathrm{sqm}$ ) with a semi-basement and $2 \frac{1}{2}$ storeys. Design and models by Donia Zhang 


\section{Proposed Suzhou New Courtyard-Garden Houses}
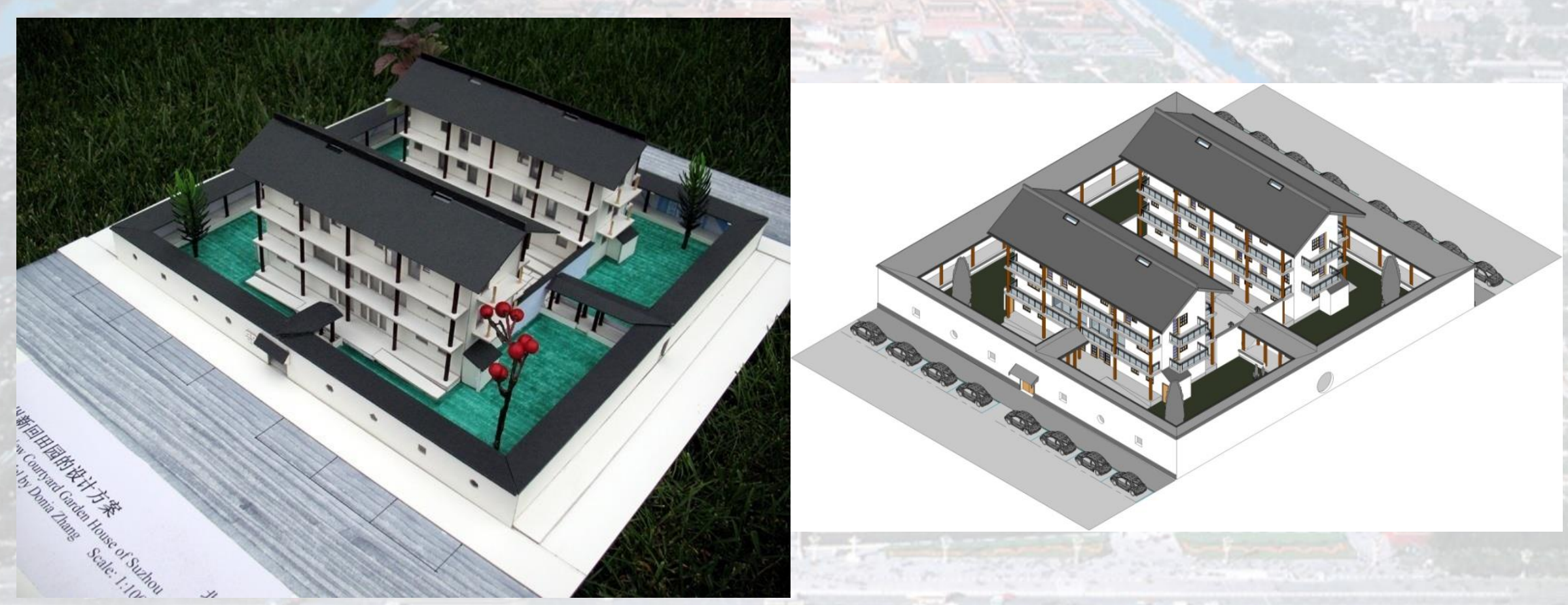

Models of the proposed Suzhou new courtyard-garden house compound based on a system of $40 \mathrm{~m} \times 40 \mathrm{~m}$ standard block size, the common courtyard is $12 \mathrm{~m} \times 20 \mathrm{~m}$ shared by 4 nuclear families, and each household also enjoys a private garden on the side. Each housing unit measures $6 \mathrm{~m} \times 10 \mathrm{~m}$ (total $180 \mathrm{sqm}$ ) with 3 storeys. Design and models by Donia Zhang 


\section{Thank you}

Presentation based on my PhD thesis completed at Oxford Brookes University (2006-2012), which has been published as a book, Courtyard Housing and Cultural Sustainability: Theory, Practice, and Product by Ashgate/Routledge (2013/2016)
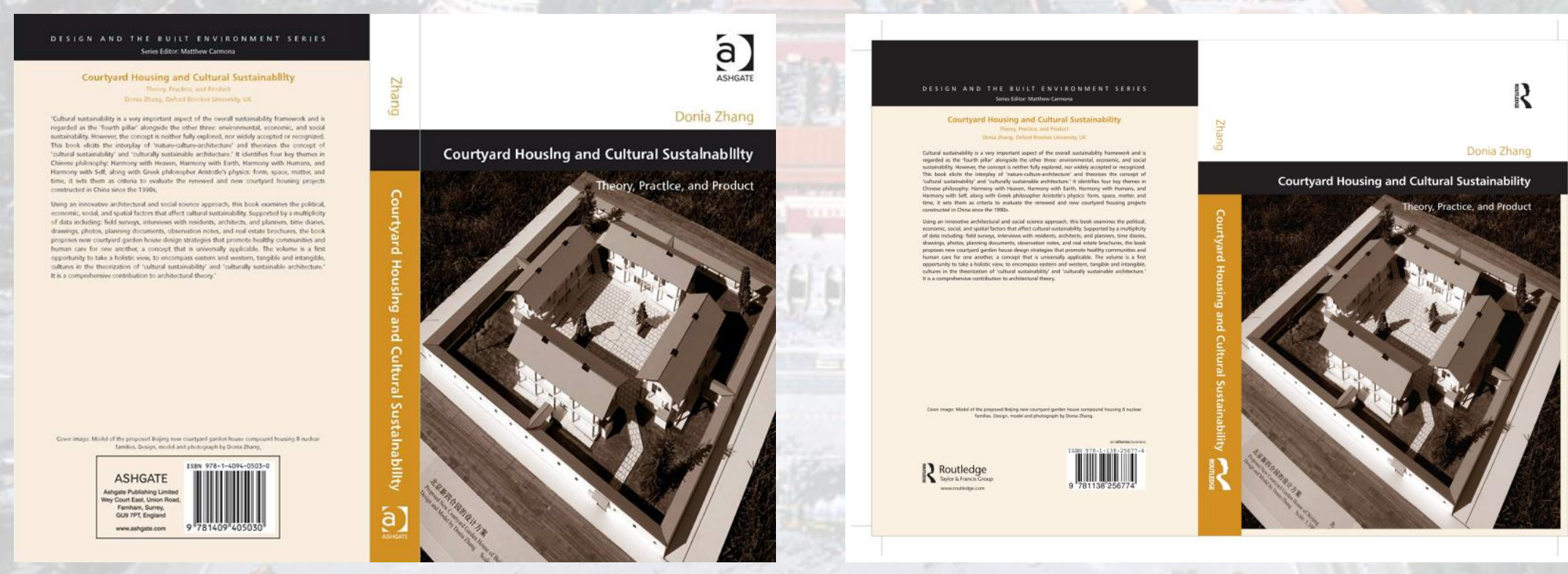